\title{
Alcoholism and Alcohol Psychoses Trends in Russia
}

\author{
Yury Evgeny Razvodovsky \\ Grodno State Medical University, Belarus
}

\begin{abstract}
Background: Russia has one of the highest incidence rates of alcoholism and alcohol psychoses in Europe, which may be explained by high overall population drinking and prevalence of irregular heavy drinking of vodka. Aims: To estimate the aggregate level effect of alcohol consumption on the alcoholism/ alcohol psychoses incidence rates in the Russian Federation. Method: Trends in alcoholism/alcohol psychoses incidence rates and alcohol consumption per capita from 1970 to 2015 were analyzed employing an ARIMA (autoregressive integrated moving average) analysis. Results: Alcohol consumption per capita is a statistically significant factor associated with alcohol psychoses incidence rate, implying that a 1-I increase in per capita alcohol consumption is associated with an increase in the alcoholic psychoses incidence rate by $17.1 \%$. Conclusion: This time-series analysis highlights close temporal association between alcohol psychoses rate and population drinking in Russia.
\end{abstract}

Key words: alcoholism/alcoholic psychoses, ARIMA time series analysis, Russia, 1970-2015.

Copyright @ 2020 KBCSM, Zagreb

e-mail: alcoholism.kbcsm@gmail.com•www.http://apr.kbcsm.hr

\section{Introduction}

Alcoholism (alcohol dependence) is one of the most common psychiatric disorders in many European countries [1]. Russia has one of the highest incidences of alcoholism and alcohol psychoses in Europe [1], which may be explained by high overall population drinking and prevalence of irregular heavy drinking of vodka $[5,9,10,13,16]$. Some estimates suggest that a total number of alcoholics (alco-

\section{Correspondence to:}

Yury Evgeny Razvodovsky, MD, PhD

Grodno State Medical University,

80 Gorky Street, Grodno 230009, Belarus

Phone: + 37501527018 84, fax: +3750152435341

E-mail: razvodovsky@tut.by,yury_razvodovsky@mail.ru hol-dependent individuals) in the late-Soviet Russia were ranging between 23 and 28 millions [15]. Currently, there are approximately 3 million alcoholics in Russia, and the number of heavy drinkers is three to four times that number [10]. Previous findings based on Russian data suggest that the incidence of alcohol psychoses is considered to be one of the most reliable indicators of alcohol-related problems closely correlating with population drinking $[2,14]$. At the same time, the incidence of alcoholism shows no correlation with the level of alcohol consumption per capita. Instead, it correlates positively with the number of doctors-narcologists (a doctor who specializes in narcology) [2]. 
This study examines the phenomenon of high alcohol dependence and alcohol psychoses rate in Russia. More specifically, this study focuses on a comparative analysis of trends in alcohol consumption per capita and alcoholism/alcohol psychoses incidence rates in Russia from the late-Soviet to postSoviet period.

\section{Methods}

\section{Data}

Alcohol psychosis is a secondary psychosis that usually occurs in alcohol-dependent individuals after the prolonged period of heavy drinking and withdrawal [12]. We specified the incidence of alcohol psychosis as the number of persons who were admitted to the hospital for the first time with alcoholic psychoses (ICD-10: F 10). Since alcohol psychosis is a disease in which patients are usually admitted to the hospital, first admission figures are good proxy of the real incidence. The ratio AP/AD showing the share of alcohol psychoses in the structure of alcohol dependence morbidity was calculated as alcohol psychoses (AP) incidence rate / alcohol dependence (AD) incidence rate $\mathrm{x} 100$. The data on alcoholism/alcohol psychoses incidence rates (per 100.000 of the population) between 1970 and 2015 are taken from the Russian State Statistical Committee (Rossstat). The total level of alcohol consumption (in litres of pure alcohol) has been estimated using the indirect method based on the alcohol poisonings mortality rate $[9,13]$.

\section{Statistical analysis}

The ARIMA (autoregressive integrated moving average) modeling technique was used to evaluate the relationship between changes in the alcohol consumption per capita and the alcohol dependence/alcoholic psychoses incidence rates across the study period. This method is most commonly used to reduce the risk of spurious trend relationship [3]. The first difference of $\log$ transformed time series was used to remove time trends. The final models were tested using the Ljuing-Box Q statistics. A time series analysis was performed using the statistical package "Statistica 12. StatSoft."

\section{Results}

The trends in the alcohol dependence and alcohol psychoses incidence rates in Russia during the late-Soviet and post-Soviet period are displayed in Figure 1. The graphical evidence suggests that the temporal pattern of alcoholism and alcohol psychoses incidence rates differ markedly. As can be seen, the alcohol psychoses incidence rates fluctuated greatly over the period: increased substantially during 1970s, decreased markedly from 1980 to 1984 , dropped sharply between 1984 - 1987, than started on an upward trend from 1987 - 1992, before jumping dramatically during 1992 to 1995. From 1995 - 1998 there was a fall in the rates before they again jumping between 1998 and 2003 and then started to decrease in the most recent years. The incidence of alcoholism increased dramatically during 1970s reaching its peak in 1980, and then dropped sharply between 1987 and 1992. There were also spikes in the incidence of alcoholism in 1994 and 2003. The graphical evidence also suggests that the temporal pattern of alcohol psychoses incidence rate and the ratio in alcohol psychoses incidence rate to alcoholism incidence rate fits closely with changes in alcohol consumption per capita (Figure 2). 


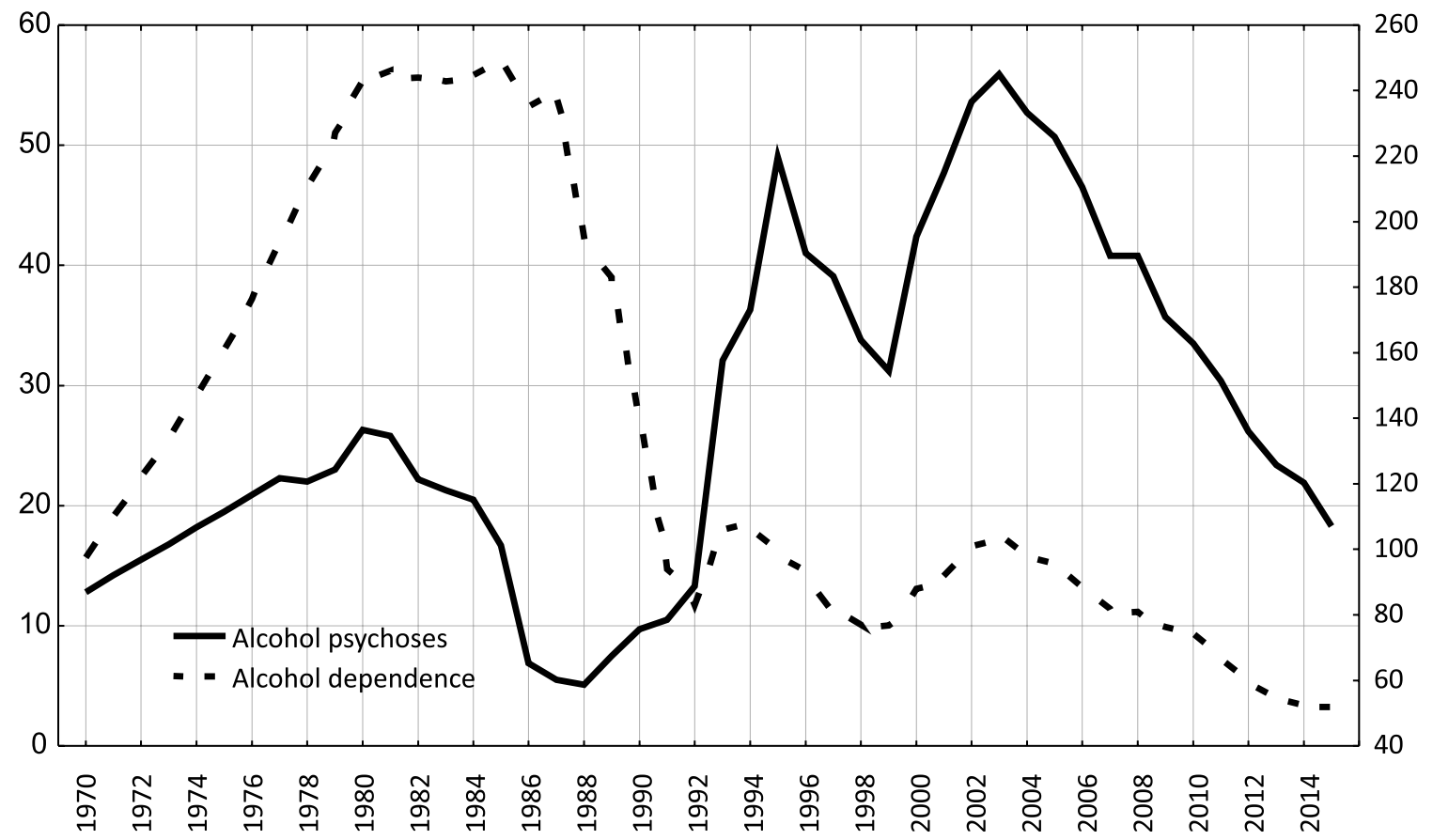

Figure 1. Trends in alcohol dependence (right scale) and alcoholic psychoses incidence (left scale) raters in Russia between 1970 and 2015.

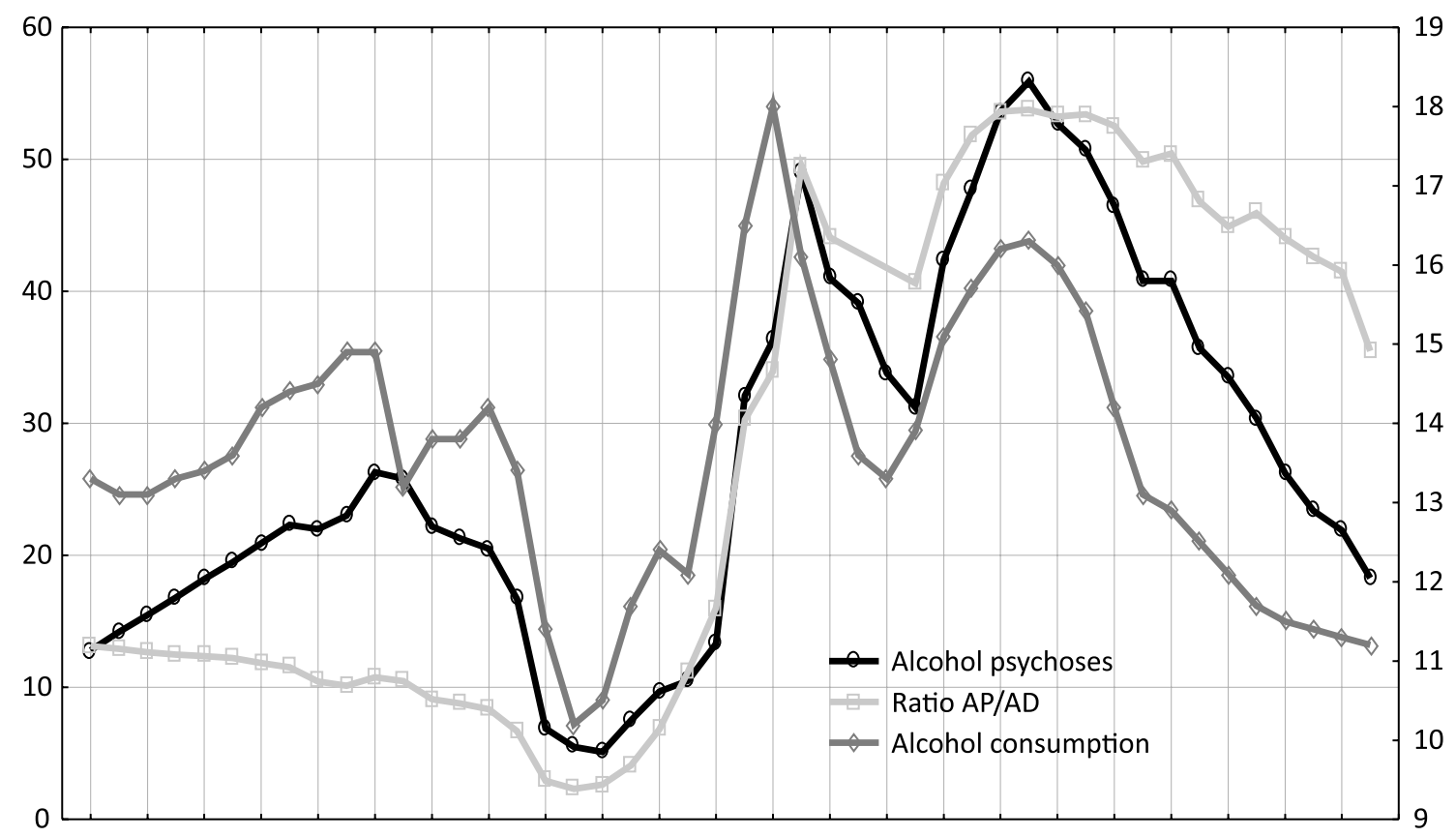

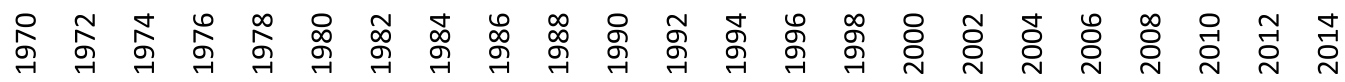

Figure 2. Trends in alcohol consumption per capita (right scale), alcohol psychoses rate (left scale) and the ratio AP/AD (left scale) in Russia between 1970 and 2015. 
A Spearman's rank correlation analysis suggests a positive association between alcohol consumption per capita and alcohol psychoses incidence rate $(\mathrm{r}=0.61 ; \mathrm{p}<0,000)$, as well as the ratio AP/AD ( $\mathrm{r}=0.36 ; \mathrm{p}<0,015)$. The association between population drinking and alcoholism incidence rate was also positive, but statistically not significant $(\mathrm{r}=0.2$; $\mathrm{p}<0,173)$.

There were sharp trends in the time series data across the entire study period. These systematic variations were well accounted for by the application of first-order differencing and the specification of a first order moving average parameter. After prewhitening, the cross-correlations between alcohol consumption and alcoholism/alcohol psychoses incidence time series were inspected. The outcome indicated statistically significant cross-correlation between alcohol consumption per capita and alcohol psychoses incidence rate $(\mathrm{r}=0.56 ; \mathrm{SE}=0.149)$, as well as the ratio $\mathrm{AP} / \mathrm{AD}(\mathrm{r}=0.37$; $\mathrm{SE}=0.149)$ at lag zero. At the same time, there were no cross-correlations between prewhitened alcohol consumption and alcoholism incidence trends: these series were therefore not included in the model estimations. According to the results of ARIMA analysis, alcohol consumption is a statistically significant factor associated with alcohol psychoses incidence rate, as well as the ratio $\mathrm{AP} / \mathrm{AD}$, implying that a 1-litre increase in consumption per capita is associated with an increase in the alcoholic psychoses incidence rate by $17.1 \%$ and an increase in the ratio $\mathrm{AP} / \mathrm{AD}$ by $14.5 \%$

\section{Discussion}

The trends in the incidence of alcoholism and alcohol psychoses in late-Soviet and post-Soviet Russia should be discussed in the context of social changes, quality of health care and the laws regulating production and sales of alcohol. During the last decades, Soviet and later Russian governments adopted a series of measures in an attempt to curb the alcohol-related burden. In 1972 a resolution by the Communist Party Central Committee "About the Measures Restricting Alcohol Consumption" was passed [10]. According to the document, the production of vodka and the number of shops selling it were to be cut. In 1974, the Russian Federation Supreme Soviet ratified a decree creating a system of special institutions (medical-labor dispensaries) within the Ministry of Internal Affaires for the long-term compulsory treatment of advanced alcoholics manifesting antisocial behavior [4]. Noncriminal alcoholics, who violate "labor discipline, public order, and the rules of social community", could be committed for one- to two-year in these explicitly penal institutions.

Despite these efforts, during the 1970s, there was a dramatic growth in the incidence of alcohol dependence reported by official statistics. To some extent this growth reflects the active development of the narcological service, which was officially created in 1976 according to the Order of the Ministry of Health of the USSR №131 [10]. Before 1976, narcological assistance to alcohol-dependent patients was made by psychiatrists in the structure of general psychiatric clinic. Since 1976, the narcological service grew rapidly, reaching its peak of funding and access to resources during the anti-alcohol campaign in 1985-1988 [12]. This led to the creation of the narcological in-patient and out-patient departments, as well an increase in the number of specialists in the field of narcology [4]. The overall structure of the narcological care system in post-Soviet Russia had not changed 
significantly since the 1970s. In general, it presented by two main types of facilities that organized according to administrative and territorial boundaries: the outpatients clinic (dispensary) and hospital, which generally provide care for the population residing in a specific territory.

Gorbachev's anti-alcohol campaign in the 1985-1988 is the most well-known natural experiment in the field of alcohol policy [10]. It seems obvious that sudden decline in alcohol psychosis incidence during this time appears to be entirely due to anti-alcohol campaign that significantly reduced alcohol consumption by limiting its manufacture and availability [5]. The collapse of the Soviet Union and the ending of the state's alcohol monopoly in January 1992 were accompanied by a sharp rise in alcohol consumption and alcoholic psychoses incidence rates [16].

It is possible that increase in alcohol psychoses incidence rates in Russia in the mid1990s, at least partly, is a consequence of deterioration in the quality of health care system, following the collapse of Soviet Union in late 1991 [4]. A process of destruction of the state-funded narcological service that began in 1989 continued in the 1990s [2]. During the 1990s, several important changes linked to broader post-Soviet socioeconomic transformation had significant effect on the addiction treatment system. In connection with the dismantling of the Soviet administrative economy generally and the restructuring of the health care sector in particular, the narcological service experienced the budgetary cutbacks [4]. In relation to this the total number of hospital beds has decreased and the length of stay in hospital has shortened. Shortages of medications and stuff were also common [10]. During this time state-run narcological service found themselves compet- ing with an "alternative medicine". As part of the freedom granted entrepreneurial efforts, there arose private narcological help, which worked on a principle of anonymity. The negative side of this private sector was that is had a single contact with alcoholics, which is a poor basis for lasting remission.

Other changes came with the abolishment of compulsory treatment laws and the commercialization of narcology [4]. After the collapse of the Soviet Union, Russia had moved to dismantle the punitive element of the narcological system and medical-labor dispensaries were formally disbanded in 1994 [10]. The commercialization was directly linked to treatment methods such as "chemical isolation" (implantation of disulfiram), and a type of hypnosis known as emotional-stress psychotherapy or "kodirovanie" which use the fear of death to prevent the patient from drinking [4]. These treatment methods represented the main sources of additional income for physicians working in the state-run network [10]. Many other aspects of alcoholism treatment in Russia had been radically reformed during the 1990s. In particular, anonymous forms of treatment have become much more popular [11]. It should be noted that these changes could be partially explained by a shift in treatment practices from long-term to short-term in-patients treatment and from in-patient to out-patient treatment [4].

Official statistics appear to show a gradual decrease in the incidence of alcoholism since 1987. However, many experts believe that these trends are misleading and that the incidence of alcohol dependence is actually increasing [2]. The fact that official statistics on alcoholism are misleading could be attributable to degradation and disorganization of narcological service. It should be stated that the rates of alcoholism incidence is influ- 
enced by a number of factors. In particular, it is influenced by sharp decrease in the number of state-run narcological clinics and doctors [11]. Besides, due to expansion of anonymous forms of treatment, a significant part of alcoholics failed to get registered at narcological establishments. At the same time, patients with alcoholic psychosis practically always undergo in-patient treatment in staterun narcological service [4].

Since 2003, Russia has experienced steep decline in the alcohol psychoses incidence rate which might be attributed to the implementation of the alcohol policy reforms, which increased government control over the alcohol market [6-8]. There is, however, some doubt that recent decline in alcoholic psychoses incidence rate in Russia is fully attributable to the alcohol control measures, since downward trend in alcohol psychoses incidence rate started before the implementation of the alcohol policy reforms.

In conclusion, according to the results of present study there was a positive and statistically significant effect of per capita alcohol consumption on alcohol psychoses incidence rate in Russia. These findings suggest that the alcohol psychoses incidence rate is a good proxy for population drinking. The outcomes of this study also indicate, that the ratio in alcohol psychoses incidence rate to alcohol dependence incidence rate is considered to be an indicator of the efficiency of narcological service regarding early diagnosing and treatment for the alcohol dependence. The higher this ratio, the bigger is the number of alcohol-dependent individuals getting into doctor's eyeshot at advanced stages of the disease. The outcomes also provide indirect support for the hypothesis that the dramatic fluctuations in the alcohol psychoses incidence rate in Russia during the last decades were related to the availability/affordability of alcohol.

\section{Acknowledgements}

None.

\section{Conflicts of interest}

None to declare.

\section{References}

1. Anderson P, Baumberg B. Alcohol in Europe. $A$ public health perspective London: Institute of Alcohol Studies; 2006.

2. Averbach YK, Shamota AZ. Potreblenie alcoholia i necotorye pocazately alcoholizacii naselenia. Voprosy narcologii. 1992;2:33-7.

3. Box GEP, Jenkins GM. Time Series Analysis: forecasting and control. London: Holden-Day Inc.; 1976.

4. Krasnov VN, Gurovich I. History and current condition of Russian psychiatry. Int Rev Psychiatry. 2012;328-33.

5. Moskalewicz J. Razvodovsky YE., Wieczorek $\ell$. East-West disparities in alcohol-related harm. Alcohol Drug Addict. 2016;29:209-22.

6. Nemtsov AV, Razvodovsky YE. Russian alcohol situation in false mirror. Alcohol Alcohol. 2016;51:626-7.

7. Nemtsov AV, Razvodovsky YE. Alcohol-related situation in Russia in the context of alcohol control policy. Sobriology. 2016;4:66-74.

8. Nemtsov AV, Razvodovsky YE. Russian alcohol policy in false mirror. Alcohol Alcohol. 2016;51:626-27.

Archives of Psychiatry Research 2020;56:33-40 
9. Nemtsov AV, Razvodovsky YE. The estimation of the level of alcohol consumption in Russia: a review of the literature. Sobriology. 2017;1:78-88.

10. Nemtsov AV. A contemporary history of alcohol in Russia. Stockholm: Sodertorns hogskola; 2011.

11. Raikhel E. Post-Soviet Placebos: Epistemology and Authority in Russian Treatments for Alcoholism. Cult Med Psychiatry. 2010;34:132-68.

12. Razvodovsky YE. Alcoholism and alcoholic psychosis in Belarus in 1970-1999. Zh Nevrol Psikhiatr Im S S Korsakova. 2002;102:58-63.

13. Razvodovsky YE. Estimation of the level of alcohol consumption in Russia. ICAP Periodic Review Drinking and Culture. 2013;8:7-10.
14. Razvodovsky YE. The effect of beverage type on alcoholic psychoses rate in Russia. Alcohol Alcohol. 2015;50:200-5.

15. Segal BM. The drunken society - alcohol abuse and alcoholism in the Soviet Union. New York: Hippocrene Books; 1990.

16. Stickley A, Leinsalu M, Andreew E, Razvodovsky YE, Vagero D, McKee M. Alcohol poisoning in Russia and the countries in the European part of the former Soviet Union, 1970-2002. Eur J Public Health. 2007;17:444-9.

\section{Trendovi alkoholizma i alkoholnih psihoza u Rusiji}

Sažetak: Rusija ima jednu od najviših stopa incidencije alkoholizma i alkoholnih psihoza u Europi, što se može objasniti visokim općim pijenjem stanovništva i učestalošću neredovitog pijenja votke. Ciljevi: Procijeniti ukupni učinak konzumacije alkohola na stopu učestalosti alkoholizma/psiholoških psihoza u Ruskoj Federaciji. Metoda: Trendovi incidencije alkoholizma / alkoholnih psihoza i potrošnje alkohola po glavi stanovnika u razdoblju od 1970. do 2015. analizirani su korištenjem ARIMA (autoregresivni integrirani pomični prosjek). Rezultati: Potrošnja alkohola po glavi stanovnika je statistički značajan faktor povezan s stopom učestalosti alkoholnih psihoza, što upućuje na to da je porast potrošnje od 1 I alkohola po glavi stanovnika povezan s povećanjem stope učestalosti alkoholnih psihoza za 17,1\%. Zaključak: Ova analiza vremenskih nizova naglašava tijesnu vremensku povezanost između stope alkoholnih psihoza i pijenja stanovništva u Rusiji.

Ključne riječi: alkoholizam/alkoholne psihoze, analiza vremenskih nizova, ARIMA, Rusija, 1970-2015. 
